\title{
Itraconazole in the Treatment of Nonfungal Cutaneous Diseases: A Review
}

\author{
Ya-Chu Tsai · Tsen-Fang Tsai
}

Received: March 10, 2019 / Published online: April 30, 2019

(C) The Author(s) 2019

\section{ABSTRACT}

Introduction: The anti-inflammatory and prokinetic properties of antibiotics have been widely reported. However, the non-antifungal properties of antifungal agents are less well known and less explored in clinical practice. The purpose of this review was to survey the literature on the non-antifungal use of itraconazole in dermatological practice and the possible modes of action of this agent.

Methods: The PubMed database was searched for relevant articles published up to January 2017. The references in the articles identified by the search were then hand-searched for additional relevant publications.

Results: Itraconazole displays a great diversity of non-antifungal activity and has been used to treat a broad spectrum of diseases. The results of our survey reveal that itraconazole has the potential to be an alternative agent for treating

Enhanced Digital Features To view enhanced digital features for this article go to https://doi.org/10.6084/ m9.figshare.8010563.

Y.-C. Tsai

Department of Dermatology, Far Eastern Memorial Hospital, New Taipei City, Taiwan

T.-F. Tsai $(\bowtie)$

Department of Dermatology, National Taiwan University Hospital and National Taiwan University College of Medicine, Taipei, Taiwan

e-mail: tftsai@yahoo.com patients with advanced cancer (either alone or in combination with other cytotoxic chemotherapeutic drugs), especially those refractory to traditional treatments. Moreover, itraconazole acts as an anti-angiogenesis agent, induces nail growth, and modulates inflammatory or immune diseases.

Conclusion: Oral antifungal agents have many non-antifungal properties. However, the body of evidence on individual agents often remains limited due to the lack of large-scale randomized controlled studies. Although some of the findings published to date seem promising, pharmacological vigilance should be taken for off-label use in real-world practice.

Keywords: Itraconazole; Non-antifungal; Offlabel use

\section{INTRODUCTION}

Exploration of the possible therapeutic uses of medications beyond their official indications is of great interest in clinical practice. Among dermatologists, the off-label use of pharmaceutical drugs is prevalent given the rarity of many cutaneous disorders [1]. In addition, many dermatoses are considered to be trivial, with the result that they become "orphan diseases" with no medications approved for treatment of the indication. The anti-inflammatory activities of antimicrobials have been widely reported [2-4], 
Table 1 Mechanism of itraconazole in treatment of dermatologic diseases

\begin{tabular}{|c|c|c|}
\hline Action & Supposed mechanisms & $\begin{array}{l}\text { Utilization in } \\
\text { nonfungal skin } \\
\text { disorders }\end{array}$ \\
\hline Anti-malignancy & Anti-Hedgehog signaling pathway; target site on Smoothened & $\begin{array}{l}\text { Advanced basal cell } \\
\text { carcinoma }\end{array}$ \\
\hline Anti-angiogenesis & $\begin{array}{l}\text { Inhibition of endothelial cell migration, proliferation, and tube } \\
\text { formation via blocking of VEGFR2 trafficking and signaling }\end{array}$ & $\begin{array}{l}\text { Infantile hemangioma } \\
\text { Keloid and hypertrophic } \\
\text { scar }\end{array}$ \\
\hline \multirow{7}{*}{$\begin{array}{l}\text { Anti-inflammation and } \\
\text { immunomodulation }\end{array}$} & Suppression of T-lymphocyte proliferation & Mycosis fungoides \\
\hline & Phenylpiperazine ring of ITZ related to the immunosuppressive & Lichen planus \\
\hline & effect & $\begin{array}{l}\text { HIV-associated } \\
\text { eosinophilic folliculitis }\end{array}$ \\
\hline & & Sarcoidosis \\
\hline & Inhibition of neutrophil chemotaxis and movement & Palmoplantar pustulosis \\
\hline & Inhibition of interleukin-8 production & \\
\hline & $\begin{array}{l}\text { Inhibition of the formation of pro-inflammatory metabolites (i.e., } \\
5 \text {-lipoxygenase) }\end{array}$ & \\
\hline Induction of nail growth & Acceleration of nail matrix turnover rate & Yellow nail syndrome \\
\hline \multirow[t]{2}{*}{$\begin{array}{l}\text { Reduction of } \\
\text { hypersensitivity } \\
\text { reaction }\end{array}$} & $\begin{array}{l}\text { Modulation of Malassezia species (as an allergen)-induced } \\
\text { hypersensitivity reaction }\end{array}$ & $\begin{array}{l}\text { Head and neck } \\
\text { dermatitis or refractory } \\
\text { atopic dermatitis }\end{array}$ \\
\hline & & $\begin{array}{l}\text { Reducing irritation of } \\
\text { calcipotriol on scalp } \\
\text { psoriasis }\end{array}$ \\
\hline
\end{tabular}

$H I V$ human immunodeficiency virus, ITZ itraconazole, VEGFR2 vascular endothelial growth factor receptor 2

but the non-antifungal activities of antifungal agents are less well known. In this review, we explore the possible non-antifungal use of itraconazole in dermatology and discuss the possible modes of action of this agent (Table 1).

\section{METHODS}

A literature search of the PubMed database was conducted for relevant articles published up to 2017 using the search terms 'itraconazole' AND 'dermatosis,' but NOT 'fungal,' NOT 'dermatophyte,' and NOT 'onychomycosis.' We also included papers identified by hand-searching the references of the articles identified in the literature search. Articles reporting nondermatological uses and treatment mechanisms mainly focusing on antifungal effects (e.g., itraconazole in seborrheic dermatitis) were excluded from the review.

This study is based on previously conducted studies and does not contain any studies with human participants or animals performed by any of the authors. 
Table 2 Studies and case reports on the use of itraconazole in dermatologic diseases

\begin{tabular}{|c|c|c|c|c|}
\hline Disease & Dose regimen & $\begin{array}{l}\text { Type of study and } \\
\text { number of patients }\end{array}$ & Response to treatment & References \\
\hline $\begin{array}{l}\text { Advanced basal } \\
\text { cell carcinoma }\end{array}$ & $\begin{array}{l}\text { ITZ } \\
\text { Three groups: } \\
\text { (a) } 400 \mathrm{mg} / \text { day for } 1 \text { month } \\
\text { (b) } 200 \mathrm{mg} / \text { day for } 1-4 \text { months } \\
\text { (c) Control }\end{array}$ & $\begin{array}{l}\text { Cohort study, phase } \\
\text { II trial, } n=29(n: \\
\begin{array}{l}\mathrm{a}=15, \mathrm{~b}=4, \mathrm{c} \\
=10)\end{array}\end{array}$ & $\begin{array}{l}45 \% \text { decrease in cell } \\
\text { proliferation; } 24 \% \text { decrease } \\
\text { in tumor area }\end{array}$ & Kim et al. [8] \\
\hline $\begin{array}{l}\text { Infantile } \\
\text { hemangioma }\end{array}$ & ITZ $5 \mathrm{mg} / \mathrm{kg} /$ day for $2-9$ weeks & Case series, $n=6$ & $\begin{array}{l}\text { All showed at least partial } \\
\text { response in the first } \\
\text { month; significant } \\
\text { improvement after } \\
3 \text { months observation }\end{array}$ & $\begin{array}{l}\text { Ran et al. } \\
\quad[11]\end{array}$ \\
\hline $\begin{array}{l}\text { Keloid and } \\
\text { hypertrophic } \\
\text { scar }\end{array}$ & ITZ for 2-4 weeks & Case series, $n=3$ & Improved dramatically & $\begin{array}{l}\text { Okada and } \\
\text { Maruyama } \\
{[12]}\end{array}$ \\
\hline $\begin{array}{l}\text { Palmoplantar } \\
\text { pustulosis }\end{array}$ & $\begin{array}{l}\text { Two weeks of ITZ } 100 \mathrm{mg} / \text { day, } \\
\text { then maintenance dose of } \\
50 \mathrm{mg} / \text { day, } 100 \mathrm{mg} \text { every other } \\
\text { day, or } 100 \mathrm{mg} / 50 \mathrm{mg} \\
\text { alternatively }\end{array}$ & $\begin{array}{l}\text { One anecdotal } \\
\text { report }(n=7) \\
\text { and another } \\
\text { single, active-arm } \\
\text { study }(n=6)\end{array}$ & $\begin{array}{l}\text { Complete resolution of } \\
\text { pustules }\end{array}$ & $\begin{array}{l}\text { Mihara et al. } \\
\text { [14] } \\
\text { V'lckova- } \\
\text { Laskoska } \\
\text { et al. [15] }\end{array}$ \\
\hline $\begin{array}{l}\text { HIV-associated } \\
\text { eosinophilic } \\
\text { folliculitis }\end{array}$ & $\begin{array}{l}\text { ITZ } 200-400 \mathrm{mg} / \text { day for } \\
2 \text { weeks }\end{array}$ & $\begin{array}{l}\text { Single-arm, open } \\
\text { trial, } n=28\end{array}$ & $\begin{array}{l}61 \% \text { of cases showed } \\
\text { complete clearance and } \\
14 \% \text { of cases showed } \\
\text { partial response }\end{array}$ & $\begin{array}{l}\text { Berger et al. } \\
\quad[16]\end{array}$ \\
\hline $\begin{array}{l}\text { Lichen planus, } \\
\text { eruptive } \\
\text { extensive type }\end{array}$ & $\begin{array}{l}\text { Pulsed oral ITZ } 200 \mathrm{mg} \text {, bid, } 1 \\
\text { week in each month for a total } \\
\text { of } 3 \text { months }\end{array}$ & $\begin{array}{l}\text { Prospective, open- } \\
\text { labelled study, } \\
n=16\end{array}$ & $\begin{array}{l}77 \% \text { of cases ceased to } \\
\text { develop; } 55 \% \text { of patients } \\
\text { had no itch; } 33 \% \text { of cases } \\
\text { showed complete } \\
\text { flattening }\end{array}$ & $\begin{array}{l}\text { Khandpur } \\
\text { et al. [18] }\end{array}$ \\
\hline Sarcoidosis & $\begin{array}{l}\text { ITZ, fluconazole, or KTZ } \\
200 \mathrm{mg} / \text { day }+ \text { corticosteroids } \\
\text { for } 3-6 \text { months }\end{array}$ & $\begin{array}{l}\text { Single-arm, } n=18 \\
\quad(\text { ITZ }=9, \\
\text { KTZ }=1, \\
\text { fluconazole }=8)\end{array}$ & $\begin{array}{l}\text { Significant reduction in } \\
\text { number of lung lesions }\end{array}$ & $\begin{array}{l}\text { Tercelj et al. } \\
{[19]}\end{array}$ \\
\hline $\begin{array}{l}\text { Mycosis } \\
\text { fungoides }\end{array}$ & ITZ $200 \mathrm{mg} /$ day for 7 days & Case report, $n=1$ & Completely subsided & $\begin{array}{l}\text { Cooper et al. } \\
{[20]}\end{array}$ \\
\hline
\end{tabular}


Table 2 continued

\begin{tabular}{|c|c|c|c|c|}
\hline Disease & Dose regimen & $\begin{array}{l}\text { Type of study and } \\
\text { number of patients }\end{array}$ & Response to treatment & References \\
\hline \multirow[t]{2}{*}{$\begin{array}{l}\text { Yellow nail } \\
\text { syndrome }\end{array}$} & $\begin{array}{l}\text { ITZ } 400 \mathrm{mg} / \text { day, } 1 \text { week in each } \\
\text { month for a total of } 7 \\
\text { cycles, + vitamin E }\end{array}$ & Case report, $n=1$ & Marked ungual regrowth & $\begin{array}{l}\text { Luyten et al. } \\
{[25]}\end{array}$ \\
\hline & $\begin{array}{l}\text { ITZ } 400 \mathrm{mg} / \text { day, } 1 \text { week in each } \\
\text { month for a total of } \\
6-12 \text { months }\end{array}$ & Case series, $n=8$ & $\begin{array}{l}\text { Two cases cured; } 2 \text { cases } \\
\text { improved a little; } 4 \text { cases } \\
\text { showed no response }\end{array}$ & $\begin{array}{l}\text { Tosti et al. } \\
\text { [27] }\end{array}$ \\
\hline \multirow[t]{3}{*}{$\begin{array}{l}\text { Head and neck } \\
\text { dermatitis } \\
\text { (HND) or } \\
\text { refractory } \\
\text { atopic } \\
\text { dermatitis }\end{array}$} & $\begin{array}{l}\text { (1) ITZ } 200 \mathrm{mg} / \mathrm{d} \text { initially, then } \\
\text { six patients were shifted to } \\
\text { fluconazole } 200 \mathrm{mg} / \text { day or } \\
\text { KTZ } 200 \mathrm{mg} / \text { day due to the } \\
\text { insurance, total } 2 \text { months } \\
\text { (2) Maintenance phase: azole } \\
200 \mathrm{mg} \text {, biw; for a total of } \\
8 \text { months }\end{array}$ & $\begin{array}{l}\text { Retrospective } \\
\text { descriptive study, } \\
n=24\end{array}$ & 17 cases $(71 \%)$ responded & $\begin{array}{c}\text { Kaffenberger } \\
\text { et al. }[28]\end{array}$ \\
\hline & $\begin{array}{l}\text { Three groups: } \\
\text { (a) ITZ } 200 \mathrm{mg} / \text { day } \\
\text { (b) ITZ } 400 \mathrm{mg} / \text { day } \\
\text { (c) Placebo } \\
\text { all for } 7 \text { days }\end{array}$ & $\begin{array}{l}\text { RCT, double-blind, } \\
\begin{array}{l}n=53(n: \\
\mathrm{a}=18, \mathrm{~b}=17, \mathrm{c} \\
=18)\end{array}\end{array}$ & $\begin{array}{l}\text { SCORAD improved } \\
\text { prominently }\end{array}$ & $\begin{array}{l}\text { Svejgaard } \\
\text { et al. [29] }\end{array}$ \\
\hline & $\begin{array}{l}\text { Two groups: } \\
\text { (a) ITZ } \\
100 \mathrm{mg} / \text { day }+ \text { lactobacillus } \\
\text { preparation for } 8 \text { weeks } \\
\text { (b) Lactobacillus preparation } \\
\text { alone for } 8 \text { weeks; then shift to } \\
\text { the opposite regimen for } \\
\text { another } 8 \text { weeks }\end{array}$ & $\begin{array}{r}\text { RCT, cross-over } \\
\text { study, } n=34\end{array}$ & $\begin{array}{l}\text { Both groups decreased use of } \\
\text { topical steroids, } \\
\text { eosinophils, and serum } \\
\text { immunoglobulin E levels }\end{array}$ & $\begin{array}{l}\text { Ikezawa et al. } \\
{[30]}\end{array}$ \\
\hline $\begin{array}{l}\text { Reducing } \\
\text { irritation of } \\
\text { calcipotriol on } \\
\text { scalp psoriasis }\end{array}$ & ITZ $100 \mathrm{mg} /$ day for 8 weeks & $\begin{array}{l}\text { RCT, double-blind, } \\
\quad n=137\end{array}$ & $\begin{array}{l}\text { Local irritation: } 19 \% \text { (ITZ) } \\
\text { vs. } 47 \% \text { (placebo), } \\
p<0.001\end{array}$ & $\begin{array}{r}\text { Faergemann } \\
\text { et al. [32] }\end{array}$ \\
\hline
\end{tabular}

bid Twice per day, biw twice weekly, KTZ ketoconazole, RCT Randomized controlled trial, SCORAD Scoring atopic dermatitis 


\section{ITRACONAZOLE}

Itraconazole, a triazole antifungal medication, was approved by the United States Food and Drug Administration in 1992.

\section{Anti-Hedgehog Signaling Pathway, Anti- Angiogenesis, and Reverse Drug Resistance}

Itraconazole has been used to treat a variety of advanced cancers. Three mechanisms have been proposed for this antifungal medication: (1) the anti-Hedgehog (Hh) pathway; (2) anti-angiogenesis; and (3) enhancement of some cytotoxic chemotherapy agents by reversing P-glycoprotein-related resistance. The P-glycoprotein is present in some cancer cells to pump out chemotherapy drugs.

\section{Basal Cell Carcinoma}

Itraconazole has been investigated for its potential in managing advanced basal cell carcinomas (BCCs). Distinct from the antifungal mechanism of inhibiting ergosterol synthesis, the anti-Hh pathway is the main target of BCCs. Hydroxy-itraconazole, a metabolite of itraconazole, also inhibits the Hh pathway [5]. The molecular target of itraconazole is on Smoothened (SMO), a G protein-coupled receptor, but the site is distinct from that of cyclopamine and other SMO antagonists [6], which explains its effect on diseases resistant to currently available SMO antagonists. Itraconazole can be used synergistically with other SMO antagonists to control tumors. In 2010, itraconazole was demonstrated to be a $\mathrm{Hh}$ inhibitor in murine medulloblastoma and BCC; this was followed by an increase in the number of clinical human trials on itraconazole in a variety of cancer therapies $[5,7]$.

Kim et al. conducted an open-label, phase II trial to evaluate the efficacy of itraconazole in suppressing BCCs [8]. In this trial, 29 patients were allocated to two active treatment groups receiving various doses of itraconazole and one placebo-controlled group (Table 2). The results showed a decrease of $45 \%$ in cell proliferation (biomarker: ki67), of $65 \%$ in $\mathrm{Hh}$ pathway activity (biomarker: GLI1 [glioma-associated oncogene homolog 1] mRNA), and of $24 \%$ in tumor area among patients treated with itraconazole. Both participants in the placebocontrolled group and patients with a history of previous exposure to vismodegib showed no reduction in tumor size, cell proliferation, or $\mathrm{Hh}$ pathway activity. This trial confirmed the antiBCC activity of itraconazole in humans; however, the optimal itraconazole dosing regimen, long-term outcome, and efficacy compared to vismodegib still need further investigation [8].

\section{Anti-Angiogenesis}

The anti-angiogenesis characteristic of itraconazole was discovered by screening the drug library and then it was authenticated in vitro and in murine non-small-cell lung carcinoma xenograft models [9]. The results suggest that itraconazole inhibits endothelial cell migration, proliferation, and tube formation via inhibition of vascular endothelial growth factor receptor 2 (VEGFR2) trafficking and signaling [10]. Dermatological examples utilizing the anti-angiogenesis activity of itraconazole include a case series of infantile hemangioma [11] and keloid treatment $[12,13]$.

\section{Infantile Hemangioma}

In a published case series, six infants aged 2-5 months old were treated successfully with oral itraconazole $5 \mathrm{mg} / \mathrm{kg}$ per day for their infantile hemangioma. The treatment period was 2-9 weeks, and the mean follow-up time was 9.7 months. Two of the patients had local ulcers and secondary candida infection on the hemangioma lesion. All patients experienced at least partial response in the first month and significant improvement after 3 months. Few adverse events were detected, with only two cases of mild diarrhea which subsided without drug cessation [11].

\section{Keloid and Hypertrophic Scar}

Okada et al. reported three cases of keloids $(n=2)$ and hypertrophic scar $(n=1)$; all three patients showed dramatic improvement following oral itraconazole therapy for 2-4 weeks for the treatment of onychomycosis and tinea 
pedis [12]. These authors reported that the efficacy of itraconazole might be attributed to the relationship between keloids and fungal infection. On the other hand, Chui et al. proposed that the possible mechanism was based on inhibition of fibroblast growth factors and VEGFs which are involved in the pathogenesis of keloids and hypertrophic scars [13].

\section{Anti-Inflammatory and Immunomodulatory Properties}

\section{Palmoplantar Pustulosis}

One anecdotal report $(n=7)$ and another single, active-arm study $(n=6)$ demonstrated itraconazole as an effective treatment for palmoplantar pustulosis (PPP). In both studies, all patients experienced complete resolution of pustules after taking itraconazole $100 \mathrm{mg} /$ day for 2 weeks. Erythema and desquamation improved either modestly or significantly. However, all patients showed a relapse of all lesions within 1 month of discontinuation of itraconazole. Thus, a maintenance dose of $50 \mathrm{mg} /$ day, $100 \mathrm{mg}$ every other day, or $100 \mathrm{mg} /$ $50 \mathrm{mg}$ alternatively was administered in some patients until stable remission was achieved. There were no adverse events noted. A possible mechanism of itraconazole in PPP is the antiinflammatory effect. Specifically, itraconazole inhibits neutrophil chemotaxis, interleukin-8 production, and the formation of pro-inflammatory metabolites (i.e., 5-lipoxygenase) $[14,15]$.

\section{Human Immunodeficiency Virus-Associated Eosinophilic Folliculitis}

A single-arm, open trial enrolled 28 patients with human immunodeficiency virus-associated eosinophilic folliculitis [16]. Of these 28 patients, $61 \%$ had complete clearance within 2 weeks, and $14 \%$ experienced partial response. The initial itraconazole dose was $200-400 \mathrm{mg} /$ day for 2 weeks; if the optimal condition was not achieved, the dose of $200 \mathrm{mg} /$ day was increased to $400 \mathrm{mg} /$ day. In this trial, three patients were shifted to fluconazole due to adverse events or cryptococcal infection; none of them showed improvement.
The authors speculated that the reason itraconazole was effective but fluconazole was not might be due to the anti-inflammatory effect of itraconazole rather than to its antifungal effect [16].

\section{Lichen Planus}

Libow et al. were the first to report the use of itraconazole to treat lichen planus (LP) in 1998 [18]. Of the four patients in their study, two experienced complete clearance of lesions following the initiation of itraconazole treatment and two had partial response [17]. In 2009, Khandpur et al. recruited 16 patients with eruptive extensive LP to verify itraconazole as an alternative treatment for this form of LP [18]. This prospective, open-label study was designed to give pulsed oral itraconazole $200 \mathrm{mg}$ twice daily for 1 week in each month to the patients. After 3 months, the results showed that itraconazole was very effective in treating eruptive LP. New lesions ceased to develop in $77.77 \%$ of subjects, $55.55 \%$ of patients showed alleviation of pruritus, and $33.33 \%$ of patients showed a complete flattening of lesions within 3 months [18].

\section{Sarcoidosis}

Tercelj et al. designed a single-arm, interventional study to which they recruited 18 patients with stage II or III sarcoidosis to receive antifungal agents (itraconazole, fluconazole, or ketoconazole $200 \mathrm{mg} /$ day) together with corticosteroid (at usual dose, as mentioned in the article) treatment for 3-6 months [19]. Patients who had previously received prednisolone $12 \mathrm{mg}$ or $16 \mathrm{mg}$ every other day for at least 6 months with poor clinical improvement or who had a sarcoidosis relapse after discontinuation of corticosteroid therapy were enrolled in this study. The results revealed a highly significant reduction in pulmonary infiltration based on X-ray scores, significant amelioration in diffusion capacity, and significant improvement in the severity of symptoms, including cough, dyspnea, chest pain, and persistent fever of $>$ $37^{\circ} \mathrm{C}$. The mechanism was reported to be associated with an unknown immune effect. Because no fungi were identified in the lung biopsy, the authors suggested that the 
antifungal medications used to treat sarcoidosis do not work directly on the synthesis of the fungal cell membrane [19]. However, the use of itraconazole in cutaneous sarcoidosis treatment has not yet been reported.

\section{Mycosis Fungoides}

A good response to itraconazole $200 \mathrm{mg}$ /day for 7 days was reported in a patient with pathologyconfirmed plaque-stage mycosis fungoides [20]. Lesions completely subsided within 1 week. The lesions relapsed in the following and third years but again cleared within 1 week of itraconazole therapy. The authors proposed that the possible mechanism is related to the immunomodulatory activity of itraconazole [20]. In previous studies, itraconazole was proven to inhibit T-lymphocyte proliferations in vitro [21] and to have anti-inflammatory effects in vivo [22].

Various studies have revealed that the potency of azole antifungal agents, especially itraconazole, in suppressing T-lymphocyte proliferation is similar to that of cyclosporine, but that interferon- $\gamma$ and tumor necrosis factor- $\alpha$ were not significantly blocked by azole agents $[21,23]$. It has been suggested that the phenylpiperazine ring of itraconazole contributes to the anti-inflammatory activity [24]. The immunosuppressive effect might explain the treatment efficacy of itraconazole in inflammatory diseases such as mycosis fungoides and LP.

\section{Induction of Nail Growth}

\section{Yellow Nail Syndrome}

A 27-year-old woman diagnosed with yellow nail syndrome unexpectedly experienced better ungual regrowth after itraconazole pulse therapy (400 mg/day, 1 week per month) was added to her vitamin E (800 IU per day) therapy for secondary onychomycosis [25]. The initial 6 months of treatment with vitamin $\mathrm{E}$ alone showed only mild improvement of proximal nail growth. After 4 cycles of combined itraconazole and vitamin $\mathrm{E}$ therapy, the finger nails improved considerably [25]. The mechanism probably involved the acceleration of nail growth rate by itraconazole, an effect which has been observed in a number of in vivo studies. Doncker et al. found higher nail peaks and a larger mean roughness value, indicating that itraconazole had induced a quicker nail matrix turnover rate, as noted by optical profilometry [26].

However, another eight-case report demonstrated no apparent effect of itraconazole on yellow nail syndrome. In that study, oral itraconazole was administered $400 \mathrm{mg} /$ day, 1 week every month, for at least 6 months. If the nails showed improvement, the treatment time was extended to 12 months. Of the eight patients two were cured and another two showed slight improvement; no improvement was observed for the remaining four patients, and one of these even improvedr after the therapy was changed vitamin E $1200 \mathrm{mg} /$ day for 6 months [27].

\section{Reduction of the Hypersensitivity Reaction}

\section{Head and Neck Dermatitis or Refractory Atopic Dermatitis}

Itraconazole is an effective treatment for refractory atopic dermatitis, especially the unique subtype of head and neck dermatitis (HND). The treatment mechanism has been related to the hypersensitivity reaction to Malassezia species in these sebum-rich areas. In the relevant literature, the initial dose ranges from 100 to $400 \mathrm{mg} /$ day for $1-2$ weeks. A maintenance phase consisting of a weeklybased regimen should be continued to reduce recurrences. Optimal maintenance dosing regimens still need to be investigated.

One retrospective study involving 24 patients with HND reported that 17 of the patients (71\%) responded to a 2-month-long treatment with an oral azole antifungal [28]. All patients were treated with itraconazole $200 \mathrm{mg} /$ day at the start of the treatment regimen, but six were subsequently switched to fluconazole $200 \mathrm{mg} /$ day or ketoconazole $200 \mathrm{mg} /$ day due to healthcare insurance or cost issues. However, a high discontinuation rate during pulse therapy with ITZ $200 \mathrm{mg}$ twice weekly (maintenance phase) suggested that the cephalic type of atopic dermatitis might be induced by hypersensitivity of the Malassezia 
species rather than by the mere overgrowth of yeasts as occurs in seborrheic dermatitis or tinea versicolor. The authors inferred that because only a small amount of allergen could induce a prolonged hypersensitivity reaction, the twiceweekly regimen during the maintenance phase might lead to dose insufficiency that was unable to control the HND [28].

One randomized controlled trial (RCT) ( $n=53$ patients) revealed the significant efficacy of a 7-day-long therapeutic regimen of itraconazole at both 200 and $400 \mathrm{mg} /$ day compared with placebo in patients with HND. Regardless of prick tests to Malassezia antigens, itraconazole clearly improved the SCORAD index. However, other areas of body surface showed no significant improvement by global evaluation [29].

Ikezawa et al. conducted a cross-over RCT which recruited 34 subjects with refractory atopic dermatitis and a positive radioallergosorbent test (RAST) to Malassezia [30]. The subjects were distributed into two groups (A and B). Group A was given itraconazole + Lactobacillus preparation for 8 weeks, then the Lactobacillus preparation alone for the following 8 weeks. Group B was given the Lactobacillus preparation alone for 8 weeks, then a combination of itraconazole + Lactobacillus preparation for the following 8 weeks. The dosage of itraconazole was $100 \mathrm{mg}$ /day in both groups. The results revealed that eosinophil counts, serum immunoglobulin E (IgE) levels, specific IgE titers to Malassezia, and the potency or dose of concomitant topical steroids had all declined significantly at the end of the itraconazole treatment in group A and group B [30].

For the treatment of chronic atopic dermatitis [31], Sugita et al. proposed a regimen of itraconazole $100 \mathrm{mg} /$ day for 1 week, followed by itraconazole $200 \mathrm{mg}$ /week for a further 11 weeks. These authors reported that at least 3 months of treatment were required to reduce recurrence for chronic atopic dermatitis.

\section{Reducing Irritation of Calcipotriol on Scalp Psoriasis}

A double-blind, randomized, placebo-controlled study ( $n=137$ subjects) reported that the elimination of Malassezia by itraconazole
$100 \mathrm{mg} /$ day for 8 weeks significantly reduced the irritation caused by the calcipotriol solution during the treatment of scalp psoriasis (local skin irritation: $19.4 \%$ [itraconazole] vs. $47.1 \%$ [placebo]; $p<0.001)$ [32].

\section{Dosing}

The approved dose of itraconazole is 200-400 mg per day for the treatment of fungal diseases. In the studies identified in our literature search, the dose of itraconazole used to treat non-antifungal cutaneous diseases was all within this range. No serious or new adverse effects were reported. However, we still recommend close surveillance of patients using this drug for the risks of liver dysfunction, heart failure, drug-drug interaction, and thrombocytopenia.

\section{CONCLUSIONS}

In conclusion, itraconazole possesses many non-antifungal properties. However, the body of evidence on these properties remains somewhat limited due to the lack of large-scale RCTs. The case numbers in some studies are rather small, and the proposed mechanisms still need to be verified. Nevertheless, this review of published studies reveals that itraconazole may have the potential to provide better control of difficult-to-treat diseases and give directions for further investigative studies. Although some of the findings reported herein seem exciting, care should be taken when using itraconazole for these off-label indications in real-world practice.

\section{ACKNOWLEDGEMENTS}

Funding. No funding or sponsorship was received for this study or publication of this article.

Authorship. All named authors meet the International Committee of Medical Journal 
Editors (ICMJE) criteria for authorship for this article, take responsibility for the integrity of the work as a whole, and have given their approval for this version to be published.

Disclosures. Ya-Chu Tsai and Tsen-Fang Tsai have nothing to disclose.

Compliance with Ethics Guidelines. This article is based on previously conducted studies and does not contain any studies with human participants or animals performed by any of the authors.

Data Availability. This article has no associated data or the data will not be deposited.

Open Access. This article is distributed under the terms of the Creative Commons Attribution-NonCommercial 4.0 International License (http://creativecommons.org/licenses/ by-nc/4.0/), which permits any noncommercial use, distribution, and reproduction in any medium, provided you give appropriate credit to the original author(s) and the source, provide a link to the Creative Commons license, and indicate if changes were made.

\section{REFERENCES}

1. Tsai TF, Yeh TY. Allopurinol in dermatology. Am J Clin Dermatol. 2010;11:225-32.

2. Huang J, Su W, Chen X, et al. Doxycycline attenuates endotoxin-induced uveitis by prostaglandin E2-EP4 signaling. Investig Ophthalmol Vis Sci. 2015;56:6686-93.

3. Budni J, Garcez ML, de Medeiros J, et al. The antiinflammatory role of minocycline in Alzheimer's disease. Curr Alzheimer Res. 2016;13:1319-29.

4. Yi C, Zhang Z, Wang W, et al. Doxycycline attenuates peripheral inflammation in rat experimental autoimmune neuritis. Neurochem Res. 2011;36:1984-90.

5. Kim J, Tang JY, Gong R, et al. Itraconazole, a commonly used antifungal that inhibits Hedgehog pathway activity and cancer growth. Cancer Cell. 2010;17:388-99.
6. Kim J, Aftab BT, Tang JY, et al. Itraconazole and arsenic trioxide inhibit Hedgehog pathway activation and tumor growth associated with acquired resistance to smoothened antagonists. Cancer Cell. 2013;23:23-34.

7. Pantziarka P, Sukhatme V, Bouche G, et al. Repurposing drugs in oncology (ReDO)-itraconazole as an anti-cancer agent. Ecancermedicalscience. 2015;9:521. https://doi.org/10.3332/ecancer.2015. 521

8. Kim DJ, Kim J, Spaunhurst K, et al. Open-label, exploratory phase II trial of oral itraconazole for the treatment of basal cell carcinoma. J Clin Oncol. 2014;32:745-51.

9. Aftab BT, Dobromilskaya I, Liu JO, et al. Itraconazole inhibits angiogenesis and tumor growth in non-small cell lung cancer. Cancer Res. 2011;71:6764-72.

10. Nacev BA, Grassi P, Dell A, et al. The antifungal drug itraconazole inhibits vascular endothelial growth factor receptor 2 (VEGFR2) glycosylation, trafficking, and signaling in endothelial cells. J Biol Chem. 2011;286:44045-56.

11. Ran Y, Chen S, Dai Y, et al. Successful treatment of oral itraconazole for infantile hemangiomas: a case series. J Dermatol. 2015;42:202-6.

12. Okada E, Maruyama Y. Are keloids and hypertrophic scars caused by fungal infection? Plast Reconstr Surg. 2007;120:814-5.

13. Chui $\mathrm{CH}$. Treatment of keloids with itraconazole. Plast Reconstr Surg. 2008;122:681-2.

14. Mihara M, Hagari Y, Morimura T, et al. Itraconazole as a new treatment for pustulosis palmaris et plantaris. Arch Dermatol. 1998;134:639-40.

15. V'lckova-Laskoska MT, Caca-Biljanovska NG, Laskoski DS, et al. Palmoplantar pustulosis treated with itraconazole: a single, active-arm pilot study. Dermatol Ther. 2009;22:85-9.

16. Berger TG, Heon V, King C, Schulze K, et al. Itraconazole therapy for human immunodeficiency virus-associated eosinophilic folliculitis. Arch Dermatol. 1995;131:358-60.

17. Libow LF, Coots NV. Treatment of lichen planus and lichen nitidus with itraconazole: reports of six cases. Cutis. 1998;62:247-8.

18. Khandpur S, Sugandhan S, Sharma VK. Pulsed itraconazole therapy in eruptive lichen planus. J Eur Acad Dermatol Venereol. 2009;23:98-101. 
19. Tercelj M, Rott T, Rylander R. Antifungal treatment in sarcoidosis-a pilot intervention trial. Respir Med. 2007;101:774-8.

20. Cooper SM, Sheridan A, Burge S. Mycosis fungoides responding to systemic itraconazole. J Eur Acad Dermatol Venereol. 2003;17:588-90.

21. Pawelec G, Ehninger G, Rehbein A, et al. Comparison of the immunosuppressive activities of the antimycotic agents itraconazole, fluconazole, ketoconazole and miconazole on human T-cells. Int J Immunopharmacol. 1991;13:299-304.

22. Rosen T, Schell BJ, Orengo I. Anti-inflammatory activity of antifungal preparations. Int J Dermatol. 1997;36:788-92.

23. Vuddhakul V, Mai GT, McCormack JG, et al. Suppression of neutrophil and lymphoproliferative responses in vitro by itraconazole but not fluconazole. Int J Immunopharmacol. 1990;12:639-45.

24. Steel HC, Tintinger GR, Anderson R. Comparison of the anti-inflammatory activities of imidazole antimycotics in relation to molecular structure. Chem Biol Drug. 2008;72:225-8.

25. Luyten C, André J, Walraevens C, et al. Yellow nail syndrome and onychomycosis. Experience with itraconazole pulse therapy combined with vitamin E. Dermatology. 1996;192:406-8.

26. De Donker P, Pierard GE. Acquired nail beading in patients receiving itraconazole-an indicator of faster nail growth? A study using optical profilometry. Clin Exp Dermatol. 1994;19:404-6.

27. Tosti A, Piraccini BM, Iorizzo M. Systemic itraconazole in the yellow nail syndrome. Br J Dermatol. $2002 ; 146: 1064-7$.

28. Kaffenberger BH, Mathis J, Zirwas MJ. A retrospective descriptive study of oral azole antifungal agents in patients with patch test-negative head and neck predominant atopic dermatitis. J Am Acad Dermatol. 2014;71:480-3.

29. El Svejgaard, Larsen PØ, Deleuran M, et al. Treatment of head and neck dermatitis comparing itraconazole $200 \mathrm{mg}$ and $400 \mathrm{mg}$ daily for 1 week with placebo. J Eur Acad Dermatol Venereol. 2004;18:445-9.

30. Ikezawa Z, Kondo M, Okajima $\mathrm{M}$, et al. Clinical usefulness of oral itraconazole, an antimycotic drug, for refractory atopic dermatitis. Eur J Dermatol. $2004 ; 14: 400-6$.

31. Sugita T, Nishikawa A, Zhang E, et al. Atopic dermatitis and skin fungal microorganisms. INTECH Open Access Publishers. 2012; pp 123-39. https:// www.intechopen.com/books/atopic-dermatitis-dise ase-etiology-and-clinical-management/atopic-derma titis-and-skin-fungal-microorganisms

32. Faergemann J, Diehl U, Bergfelt L, et al. Scalp psoriasis: synergy between the Malassezia yeasts and skin irritation due to calcipotriol. Acta Derm Venereol. 2003;83:438-41. 